http://dx.doi.org/10.7494/drill.2016.33.3.595 Marcin Kremieniewski*, Marcin Rzepka*,
Stanisław Stryczek**, Rafal Wiśniowski**

\title{
COMPARISON OF GAS MIGRATION TEST AND BUILDING STRUCTURAL STRENGTH OF SLURRY IN THE ASPECT OF LIMITING GAS INVASION***
}

\section{INTRODUCTION}

The problem of gas flow in the annular space has been discussed since the 1960s. The flow of reservoir fluids to the annular space as a consequence of the lack of pressure balance has been analyzed. The fluid moves to the lower pressure zone, sometimes it may even reach the surface (Fig. 1).

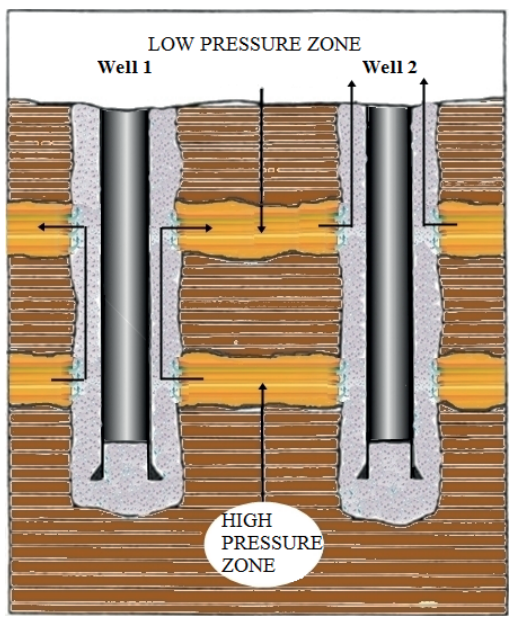

Fig. 1. Schematic of interzone migration

\footnotetext{
* Oil and Gas Institute - National Research Institute, Krakow, Poland

** AGH University of Science and Technology, Faculty of Drilling, Oil and Gas, Krakow, Poland

*** Work realized within the Blue Gas Program - Optidrilltec project financed by the National Center for Research and Development
} 
This problem is encountered in a number of gaseous deposits and wells prepared for underground gas storage purposes. This effect is frequently called gaseous connection, gas leak, gas flow in the annular space, channel gas flow, gas flow after cementing jobs or after invasion. The risk of occurrence of gas flow covers a broad range of issues, starting from delicate gas cushions on the head, to eruptions [3, 9].

Analyzing the factors influencing the gas migration process we can distinguish geological, technical, technological, mechanical and organizing factors. For the sake of eliminating this disadvantageous effect, various additives or admixtures are added to the sealing slurries to improve the parameters of the cement sheath. Gas migration tests were performed in the course of cement slurry binding. Apart from it the increase of static structural strength was also analyzed. These analyses help understand and limit the gas migration in the between pipe and annular space thanks to the recognition of processes taking place when the slurry is binding and the hydrostatic pressure lowers within the area of the cemented casing column [10].

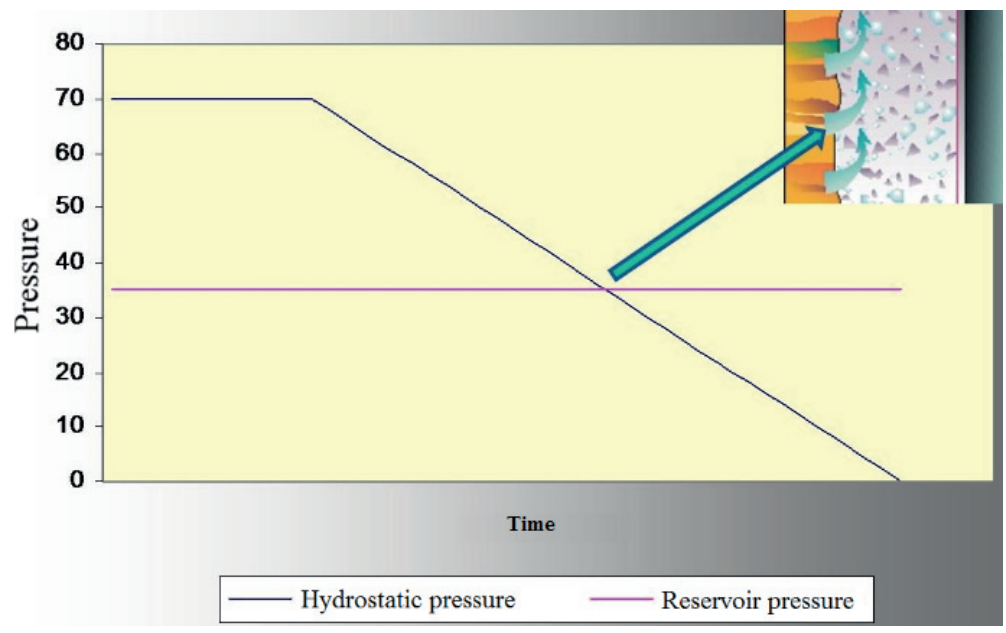

Fig. 2. Lowering of hydrostatic pressure of bonding sealing slurry

After injecting the slurry to the sealed space it undergoes binding in the time scheduled for a given well. Liquid cement slurry exerted by hydrostatic pressure counterbalances reservoir pressure. Then the slurry undergoes binding processes and its hydrostatic pressure decreases (Fig. 2). When the hydrostatic pressure lowers under the value of reservoir pressure before the end of the binding process, gas may start migrating in the sealing slurry structure (to the low pressure zone). At that time the static structural strength is built. Gas will not migrate if the slurry reaches an appropriate static structural strength (SSS) which causes the formation of a barrier hindering its exhalation. The SSS value was determined experimentally and equals to $240[\mathrm{~Pa}][1,5,7]$. Additional experiments prove the dependence of the drop of hydrostatic pressure during the test on the gas migration in the course of binding, and analyzing static structural strength. 


\section{Test of gas migration in the course of cement slurry binding}

The gas migration test was conducted with the use of the apparatus presented in Figure 3 (OGI-NRI design), simulating borehole conditions and allowing for tracing phenomena in the slurry during binding processes. The tests have been performed in the conditions simulating the cemented annular space in a well, injected gas (under pressure), and low pressure permeable zone. Cement slurry was subjected to the operation of two zones in the well-simulated conditions. The first was characterized by high gas pressure, the other one low gas pressure. Hydrostatic pressure exerted on the column stops gas migration as long as the cement slurry remains in the liquid state. When the reservoir pressure in the cement slurry decreases because of chemical dehydration below the gas pressure, it may enter the structure of the binding cement slurry to go to the surface or other low pressure zone. The gas migration tests give some knowledge about the process of invasion in the structure of the binding cement slurry, analogous as on the cement slurry/reservoir rock interface or near the interface $[11,12]$.

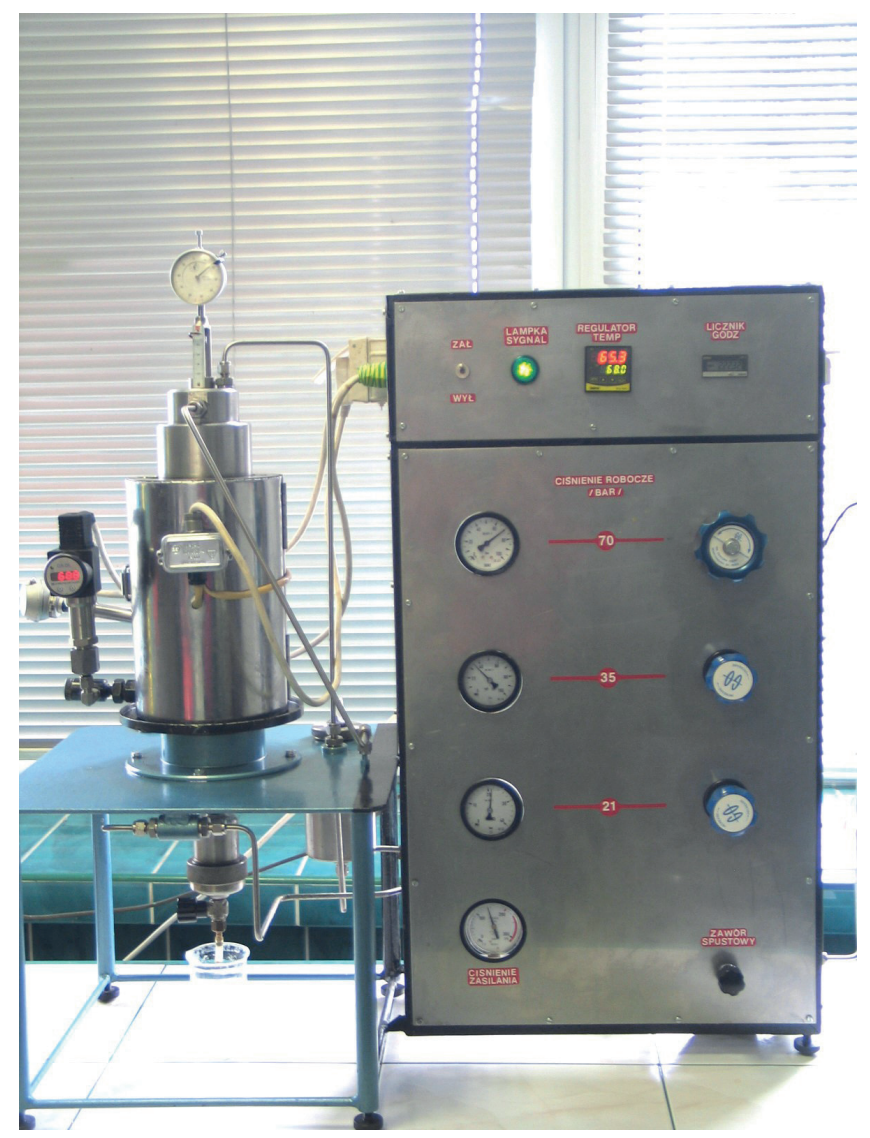

Fig 3. Apparatus for analyzing gas migration through bonding cement slurry in wellbore-like conditions 


\section{Analysis of static structural strength (SSS)}

The static structural strength has been analyzed with the use of the SGSM analyzer Ofite model 120-53 (Fig. 4). The analysis lies in determining the force exerted by paddles on the thickening sealing slurry. The paddles of definite surface performed very slow cyclic rotations (0.5 degree per minute) (Fig. 5) [4].

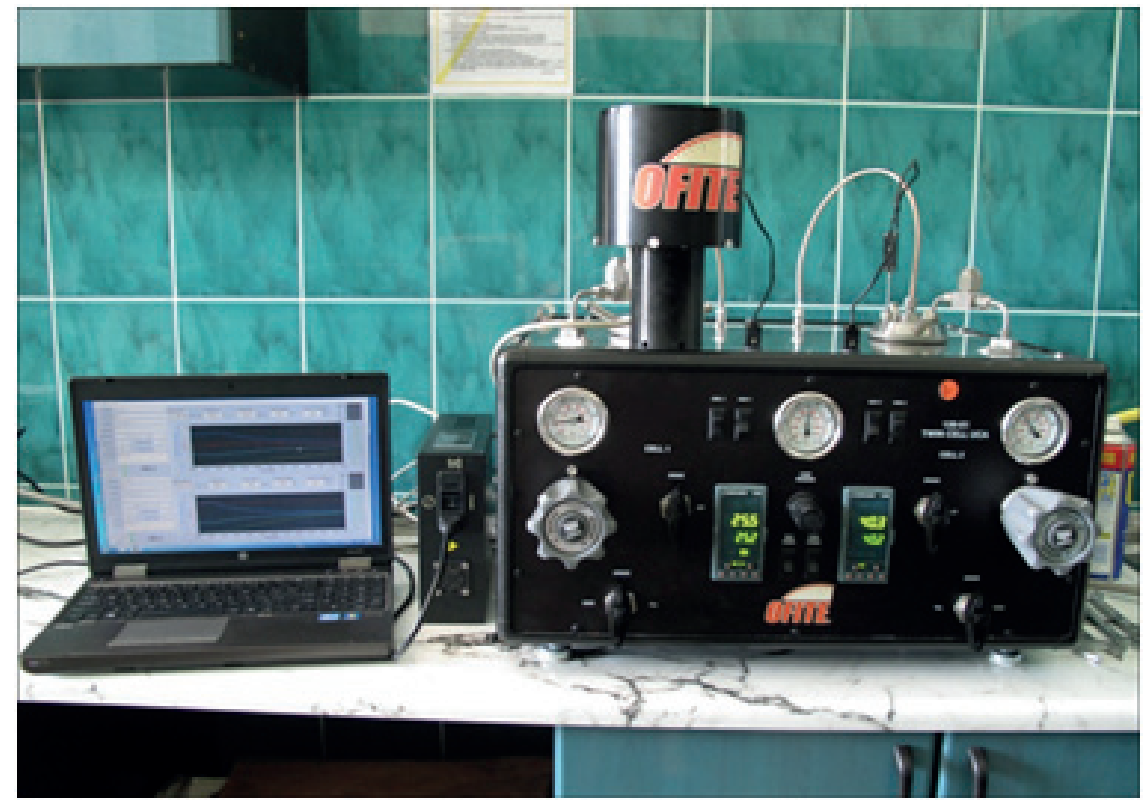

Fig 4. Two-chamber UCA SGSM Ofite model 120-53

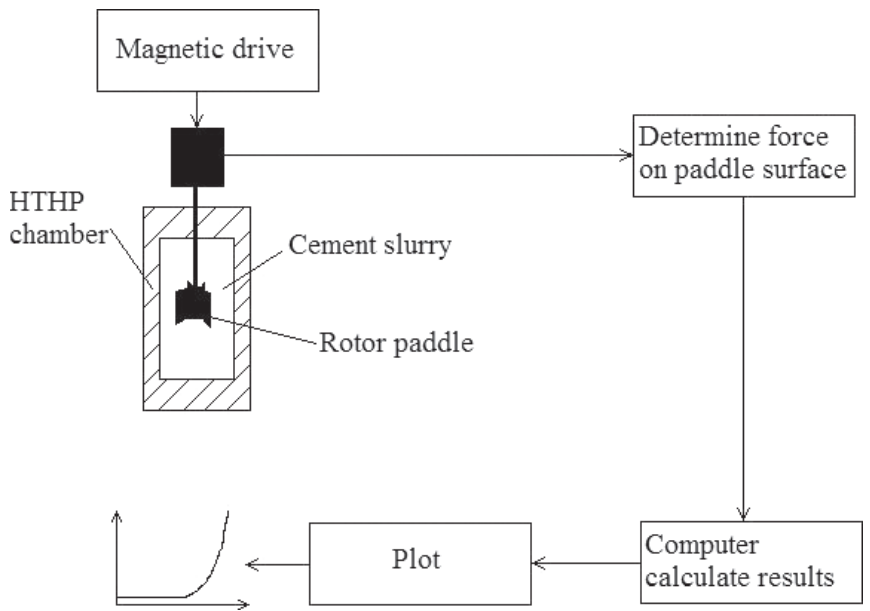

Fig. 5. Schematic of SSS measurement with SGSM Analyser 
One of the most important factors, which contribute to the stopping of gas migration in the course of slurry bonding is static structural strength (SSS). For the sake of preventing gas from entering the structure of the binding sealing slurry the recipe of the slurry should be so modified as to obtain the possibly short transition time (TT). The lower is the probability of formation of gaseous channels in the structure of the gelling sealing slurry, the shorter is the transition time TT. The analyses reveal that for typical cement slurries, where no retarders were used, the transition time TT equals up to $3 \mathrm{hrs}$, whereas slurries used for sealing deposits where the risk of gas migration occurrence is increased, have much shorter TT, frequently under $1 \mathrm{hr}$.

Transition time is a time between the first measurement of SSS and time in which cement slurry reached the state in which no new gaseous channels can be formed (Fig. 6) [2, 8]. The slurry changes its state from liquid to gel and finally to solid. This process takes place after the slurry injection beyond the casing. In this time the slurry behaves neither like a fluid nor like a solid, having properties of both these states simultaneously. During transformation the static structural strength of the slurry increases, which results from the hydration of cement. The read out of the first value of static structural strength is made at the point when the slurry leaves the liquid state, when it can fully transmit hydrostatic pressure to the state in which the hydrostatic pressure starts to decrease (point A, Fig. 6) [2]. The experimentally determined value, corresponding to this point, equals to $48 \mathrm{~Pa}\left(100\right.$ pounds $\left./ 100 \mathrm{ft}^{2}\right)$. The remaining measurement points were determined in definite time intervals, till a characteristic point in which cement slurry loses its ability to transmit hydrostatic pressure is reached. This point is defined as the beginning of the transition time of binding [2, 6] (point B, Fig. 6), and its value determined experimentally equals to $240 \mathrm{~Pa}\left(500\right.$ pounds $\left./ 100 \mathrm{ft}^{2}\right)$.

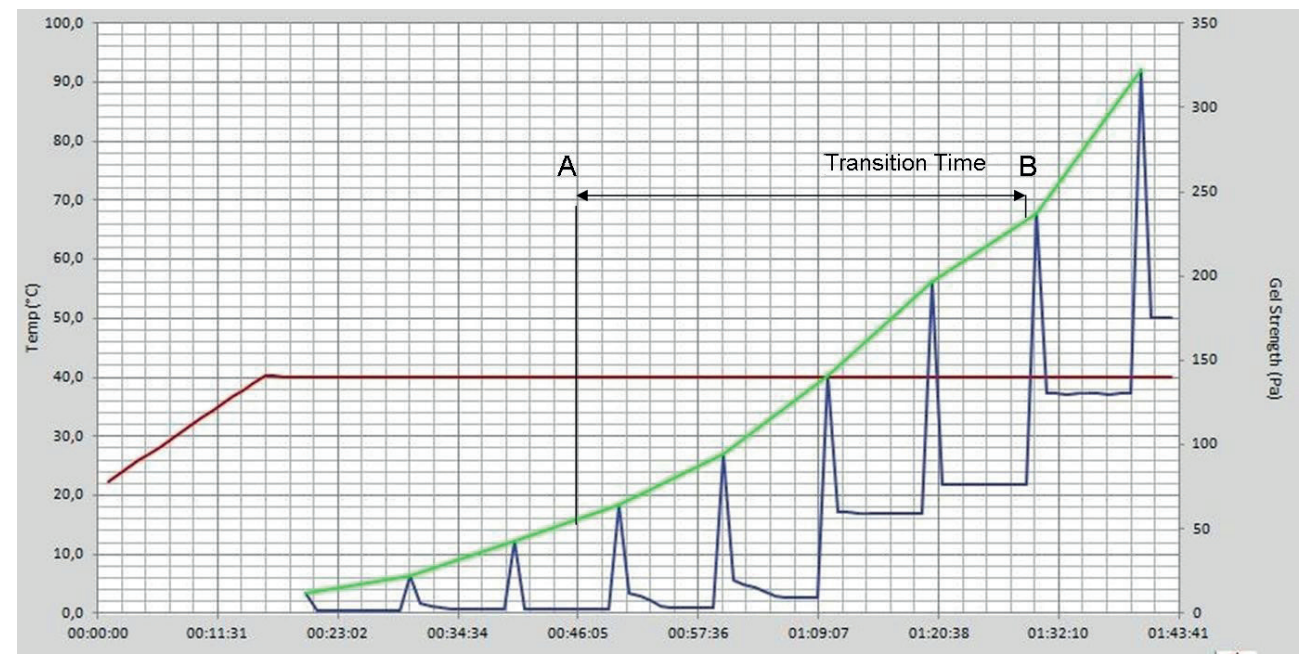

Fig. 6. Transition time of sealing slurry

Both the test for gas migration during slurry binding and the analysis of the increasing static structural strength can be used for test elaborating or modifying the composition of slurry thanks to which it can be used for sealing boreholes where the risk of gas exhalations is 
increased. The analysis of the research conducted by OGI-NRI revealed that there exists a dependence of the results of experiments describing the ability of slurry to counteract gas migration. The gas migration test for the binding cement slurry was compared with the analysis of the increasing static structural strength. The results have been presented further in this paper.

\section{LABORATORY EXPERIMENTS}

Laboratory experiments aimed at working out sealing slurries were conducted at the Laboratory of Sealing Slurries, Drilling Technology Department of OGI-NRI. The analyses were performed in line with the standards (PN-EN 10426-2: 2006. Przemyst naftowy $i$ gazowniczy - Cementy i materiaty do cementowania otworów - Czesść 2: Badania cementów wiertniczych, PN-EN 10426-2: Oil and gas engineering industry-Cements and materials used for cementing wellbores. Part 2: Analysis of drilling cements, PN-85/G-02320: 1985. Cementy i zaczyny cementowe do cementowania $w$ otworach wiertniczych, PN-85/G-02320: Cements and cement slurries for cementing jobs in wellbores, API SPEC 10: Specification for materials and testing for well cements).

Then the tests for gas migration during binding were performed for the designed slurries with the use of an OGI-NRI apparatus (Fig. 1) following the research procedure. For comparison's sake, the increase of static structural strength of cement slurry was also performed, in compliance with the standard EN-PN ISO10426-6 and with the use of SGSM analyzer Ofite model 120-53 (Fig. 4).

The analyses were performed for four slurry components. The basic slurries $1 / \mathrm{BAZ}$ and 2/BAZ were the basic compositions (not withstanding the gas migration phenomena), and 1/AMI and 2/AMI slurries were able to counteract the gas migration process. The tests were aimed at comparing both research methods. Slurries no. 1 (both BAZ and AMI) are fit for conditions corresponding to a temperature of $25^{\circ} \mathrm{C}$ and pressure $3 \mathrm{MPa}$, whereas conditions no. 2 (BAZ and AMI) corresponded to wellbore-like conditions, temperature of $60^{\circ} \mathrm{C}$ and pressure of $35 \mathrm{MPa}$.

The slurries were based on network water with Portland cement 32,5 R for slurries at a temperature of $25^{\circ} \mathrm{C}$ and drilling cement G HSR for sealing slurries at temperature $60^{\circ} \mathrm{C}$. The compositions of slurries have been presented in Table 1. The first recipe 1/BAZ, for latex slurry and without BSA addition, was basic reference slurry. The modification of this recipe is slurry $1 / \mathrm{AMI}$, with an addition of $6.5 \%$ of countermigration agent. Latex and antifiltrate were removed from slurry $1 /$ AMI and the microcement content was lowered from $20 \%$ to $5 \%$. The water-to-cement ratio was also lowered in the modified slurry.

In the case of recipes for wellbore temperature of $60^{\circ} \mathrm{C}$ and pressure of $35 \mathrm{MPa}$ the latex and antifiltrate were eliminated and $6.5 \%$ BSA was added. The microcement content was lowered from $15 \%$ to $5 \%$ and the water-to-cement ratio was increased to maintain the appropriate rheological conditions.

Thanks to these modifications the filtration of the slurries could be considerably lowered from $94 \mathrm{~cm}^{3} / 30$ minutes to $30 \mathrm{~cm}^{3} / 30$ minutes for slurry $1 /$ AMI and from $78 \mathrm{~cm}^{3} / 30$ minutes to $14 \mathrm{~cm}^{3} / 30$ minutes for slurry $2 /$ AMI. The modified slurries had lowered rheological parameters as compared to basic slurries and lack of settling. The results have been listed in Table 2. 
Table 1

Composition of compared slurries

\begin{tabular}{|l|c|c|c|c|}
\hline \multicolumn{1}{|c|}{ Composition } & Slurry 1/BAZ & Slurry 1/AMI & $\begin{array}{c}\text { Slurry } \\
2 / \mathrm{BAZ}\end{array}$ & \multicolumn{2}{c|}{$\begin{array}{c}\text { Slurry } \\
2 / \mathrm{AMI}\end{array}$} \\
\hline Slurry for conditions [temp./pressure] & \multicolumn{2}{|c|}{$25^{\circ} \mathrm{C} / 3 \mathrm{MPa}$} & \multicolumn{2}{c|}{$60^{\circ} \mathrm{C} / 35 \mathrm{MPa}$} \\
\hline Network water & $\mathrm{w} / \mathrm{c}=0.54$ & $\mathrm{w} / \mathrm{c}=0.50$ & $\mathrm{w} / \mathrm{c}=0.46$ & $\mathrm{w} / \mathrm{c}=0.50$ \\
\hline Defoamer & $1.0 \%$ & $0.2 \%$ & $0.5 \%$ & $0.2 \%$ \\
\hline Liquefier & $0.3 \%$ & $0.4 \%$ & $0.1 \%$ & $0.3 \%$ \\
\hline Antifitration agent & $0.1 \%$ & - & $0.1 \%$ & - \\
\hline Accelerator/retarder* & $3.5 \%$ & $1.0 \%$ & - & $0.3 \% *$ \\
\hline Latex & $10.0 \%$ & - & $10.0 \%$ & - \\
\hline Latex stabilizer & $2.0 \%$ & - & $2.0 \%$ & - \\
\hline BSA** & - & $6.5 \%$ & - & $6.5 \%$ \\
\hline Microcement & $20.0 \%$ & $5.0 \%$ & $15.0 \%$ & $5.0 \%$ \\
\hline Portland cement 32,5R / G HSR $* * *$ & $100.0 \%$ & $100 \%$ & $100.0 \% * * *$ & $100.0 \% * * *$ \\
\hline Swelling agent & $0.3 \%$ & $0.2 \%$ & $0.3 \%$ & $0.1 \%$ \\
\hline
\end{tabular}

* retarder

** BSA Copolymer

*** drilling cement GHSR

The most important properties which were taken into consideration during realization of the research were the time of beginning and end of bonding during the migration test when the cement slurry is bonding, and the transition time (TT) when building the static structural strength. The results have been presented in Table 2, and the graphical interpretation of the migration test during bonding and building static structural strength have been presented in Figures 7 to 14 .

Slurries 1/BAZ and 2/BAZ, which do not counteract gas migration very slowly built the static structural strength, had long transition time (TT) and time of bonding end after hydrostatic pressure dropped below the given reservoir pressure (Figs. 7, 9, 11 and 13). A reverse situation was observed in the case of slurries counteracting gas migration processes, i.e. 1/AMI and 2/AMI. These slurries have short transition times TT (below 1 hour). During the gas migration test, the time of bonding end was observed before the hydrostatic pressure dropped below the given reservoir pressure (Figs. 8, 10, 12 and 14). 
Table 2

Parameters of selected slurries

\begin{tabular}{|c|c|c|c|c|c|}
\hline \multicolumn{2}{|l|}{ Parameter } & $\begin{array}{l}\text { Slurry } \\
1 / \mathrm{BAZ}\end{array}$ & Slurry $1 / \mathrm{AMI}$ & $\begin{array}{l}\text { Slurry } \\
2 / B A Z\end{array}$ & Slurry 2/AMI \\
\hline \multicolumn{2}{|l|}{ Density $\left[\mathrm{g} / \mathrm{cm}^{3}\right]$} & 1.75 & 1.80 & 1.84 & 1.79 \\
\hline \multicolumn{2}{|l|}{ Spillability [mm] } & 240 & 210 & 300 & 200 \\
\hline \multicolumn{2}{|l|}{ Filtration $\left[\mathrm{cm}^{3} / 30 \mathrm{~min}\right]$} & 94.0 & 30.0 & $78.0^{*}$ & $14.0 *$ \\
\hline \multicolumn{2}{|l|}{ Plastic viscosity $[\mathrm{mPa} \cdot \mathrm{s}]$} & 93.0 & 82.5 & 99.0 & 89.0 \\
\hline \multicolumn{2}{|l|}{ Yield point $[\mathrm{Pa}]$} & 6.6 & 2.16 & 7.8 & 5.2 \\
\hline \multicolumn{2}{|l|}{ Structural strength $[\mathrm{Pa}]$} & 24.0 & 7.7 & 7.7 & 4.8 \\
\hline \multicolumn{2}{|l|}{ Water settling [\%] } & 1.5 & 0.0 & 0.8 & 0.0 \\
\hline \multirow{3}{*}{$\begin{array}{l}\text { Time of thickening } \\
{\left[\begin{array}{l}\text { hrs:min }] \\
\left(t=25^{\circ} \mathrm{C}, p=3 \mathrm{MPa}\right) \\
*\left(t=60^{\circ} \mathrm{C}, p=35 \mathrm{MPa}\right)\end{array}\right.}\end{array}$} & $30 \mathrm{Bc}$ & $1: 20$ & $1: 50$ & $4: 35^{*}$ & $2: 50^{*}$ \\
\hline & $100 \mathrm{Bc}$ & $3: 05$ & $2: 20$ & $7: 15^{*}$ & $3: 25 *$ \\
\hline & $\begin{array}{c}\text { Thickening } \\
30-100 \mathrm{Bc} \\
\text { [min] }\end{array}$ & $1: 45$ & $0: 30$ & $2: 40^{*}$ & $0: 35^{*}$ \\
\hline \multirow{3}{*}{ Time of SSS increase } & $\begin{array}{c}48 \mathrm{~Pa} \\
{[\text { hrs:min] }}\end{array}$ & $0: 15$ & $1: 15$ & $4: 01^{*}$ & $2: 40^{*}$ \\
\hline & $\begin{array}{c}240 \mathrm{~Pa} \\
{[\mathrm{hrs}: \mathrm{min}]}\end{array}$ & $2: 50$ & 2:06 & N/a* & $3: 15^{*}$ \\
\hline & $\begin{array}{c}\text { TT } \\
48-240 \mathrm{~Pa} \\
{[\text { hrs:min] }}\end{array}$ & $2: 35$ & $0: 51$ & N/a* & $0: 35^{*}$ \\
\hline
\end{tabular}

* Parameters: filtration, thickening time, time of SSS increase were determined at temperature $60^{\circ} \mathrm{C}$ and pressure $35 \mathrm{MPa}$

$\mathrm{N} / \mathrm{a}^{*}$ - absence 


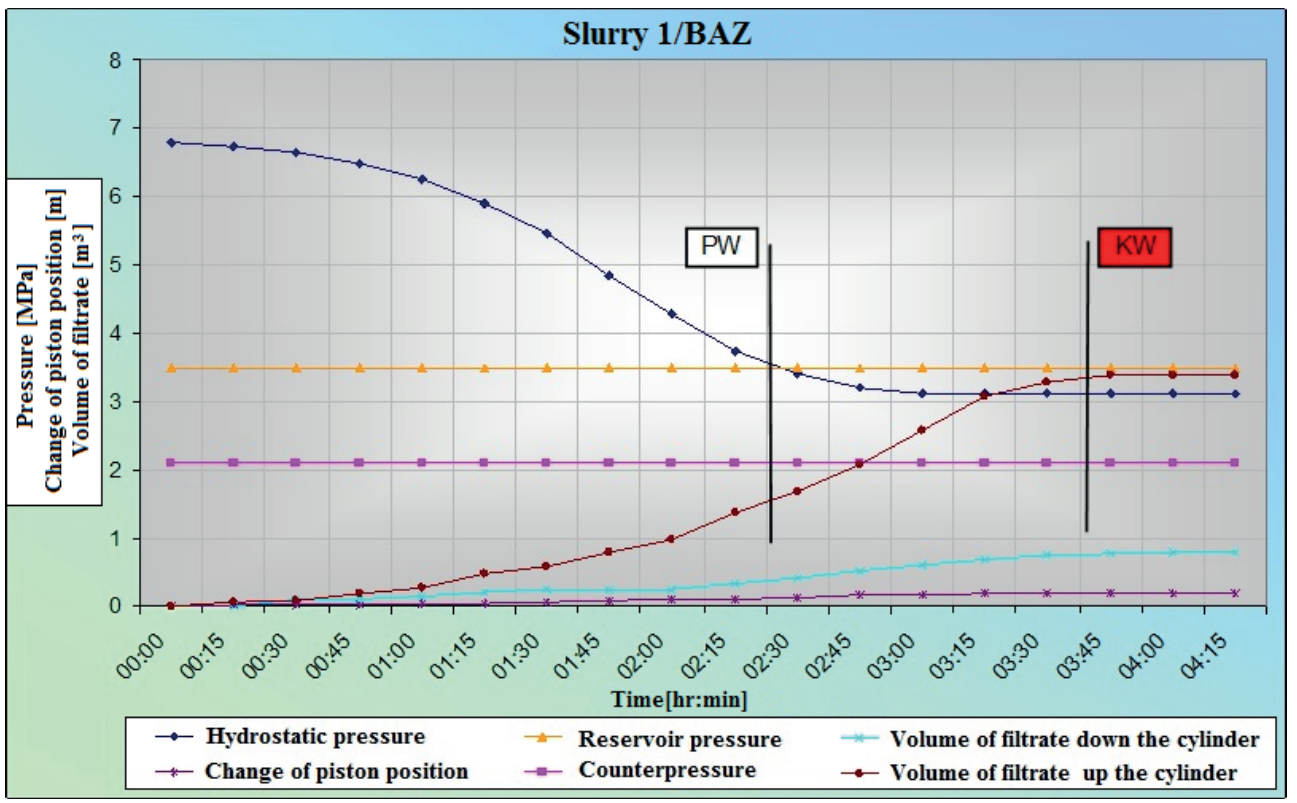

Fig. 7. Gas migration resistance test during bonding of slurry 1/BAZ. Slurries for wellbore conditions at temp. $25^{\circ} \mathrm{C}$ and pressure $3 \mathrm{MPa}$. Slurry of low resistance to gas migration

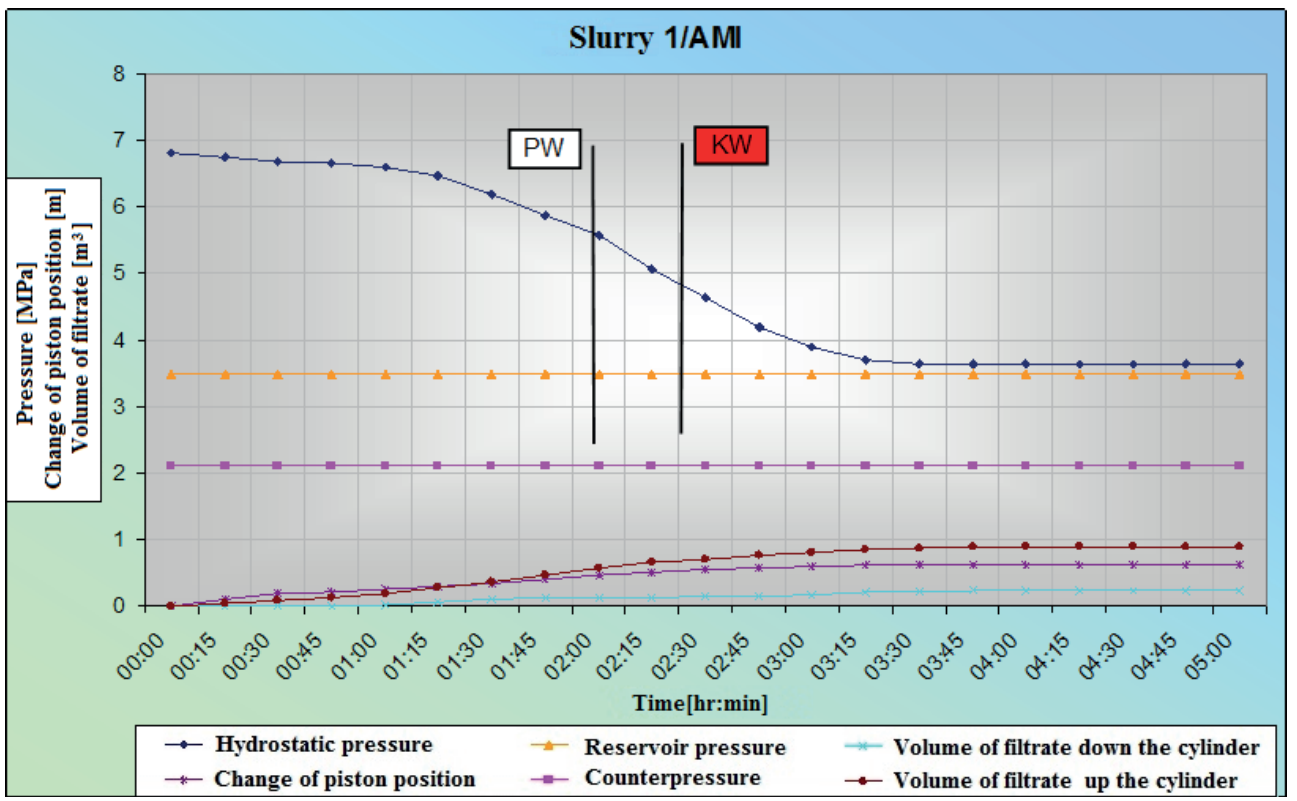

Fig. 8. Gas migration resistance test during bonding of slurry 1/AMI. Slurries for wellbore conditions at temp. $25^{\circ} \mathrm{C}$ and pressure $3 \mathrm{MPa}$. Slurry counteracting gas migration 


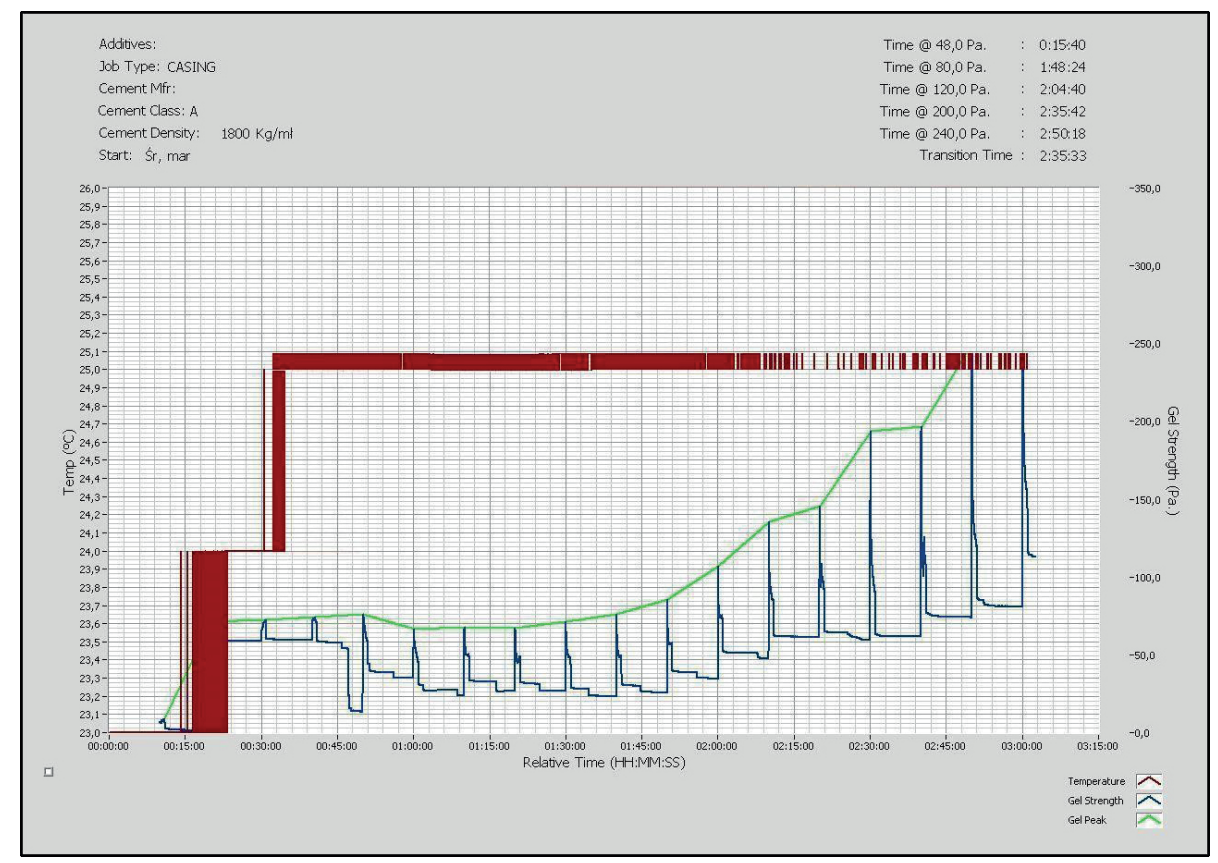

Fig. 9. Analysis of static structural strength increase of slurry 1/BAZ

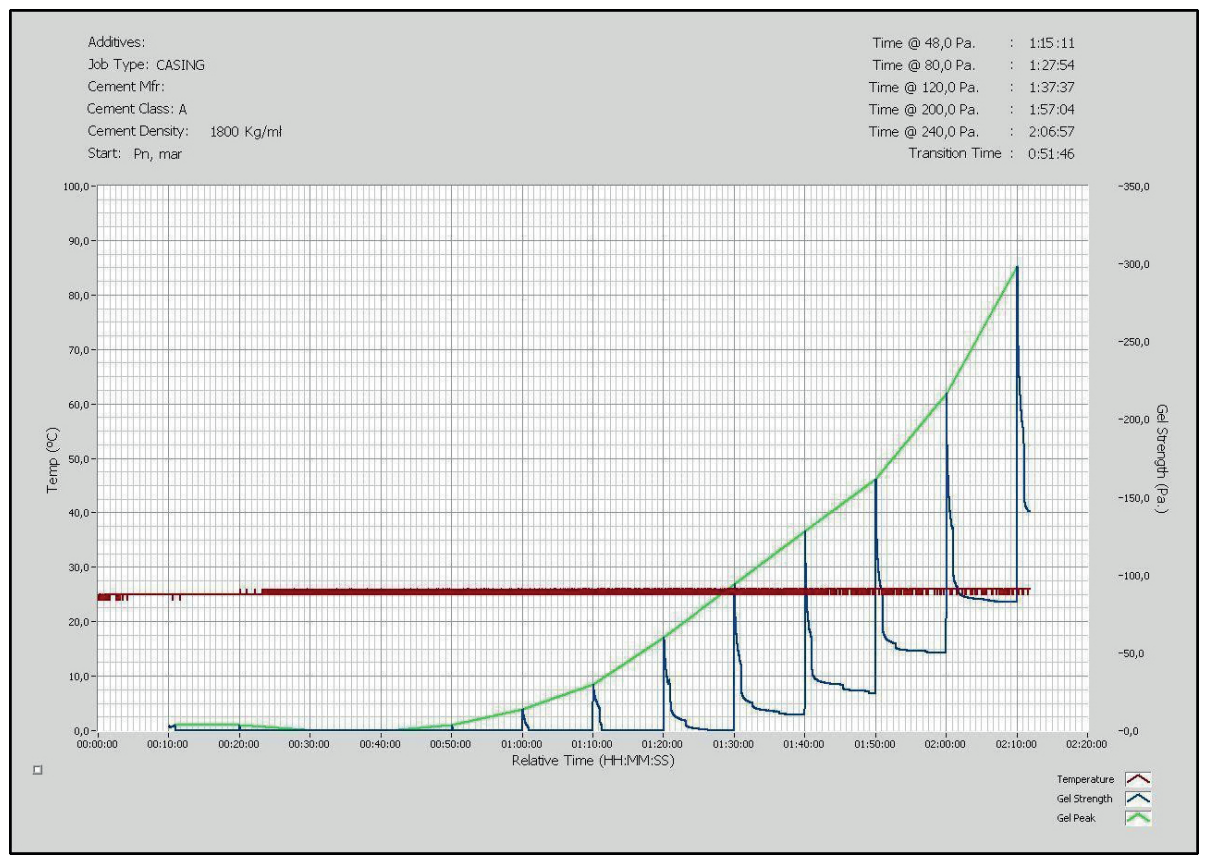

Fig. 10. Analysis of static structural strength increase of slurry 1/AMI 


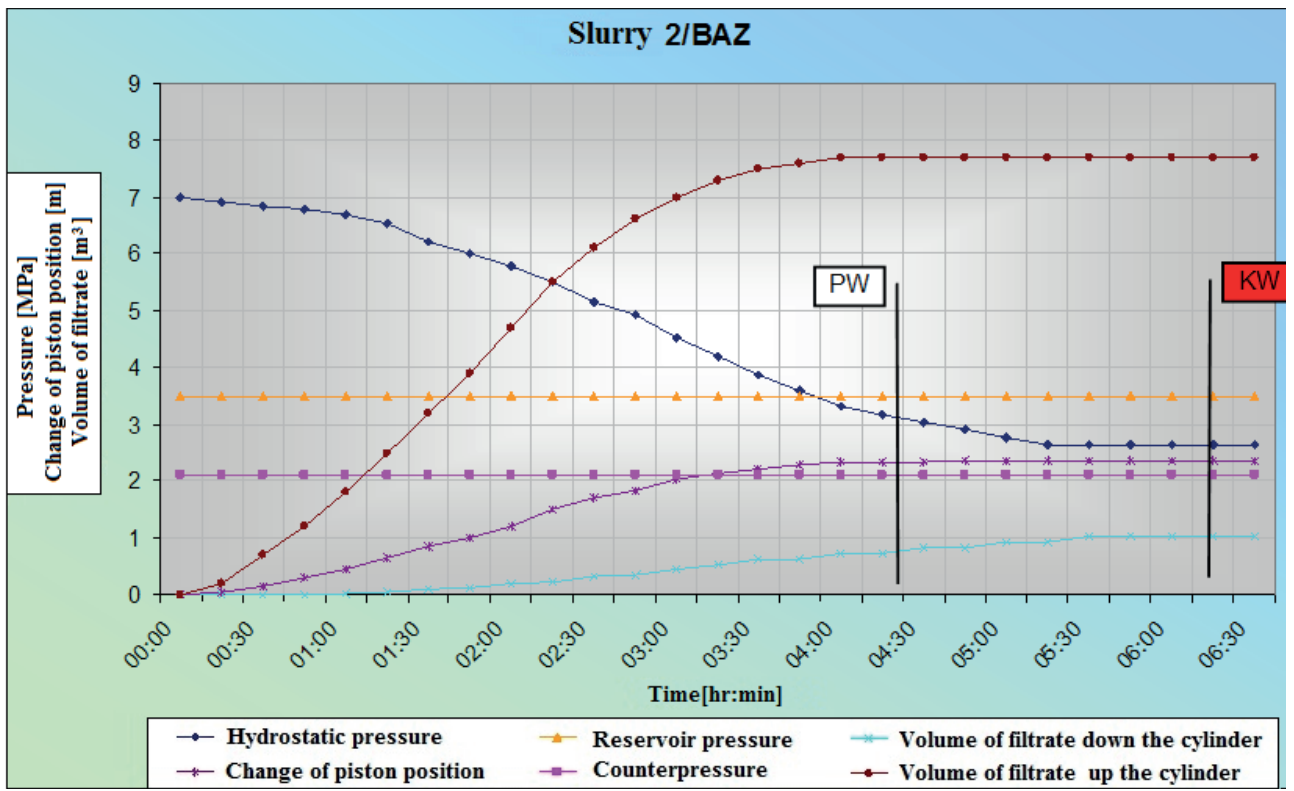

Fig. 11. Gas migration resistance test during bonding of slurry 2/BAZ. Slurries for wellbore conditions at temp. $60^{\circ} \mathrm{C}$ and pressure $35 \mathrm{MPa}$. Slurry of low resistance to gas migration

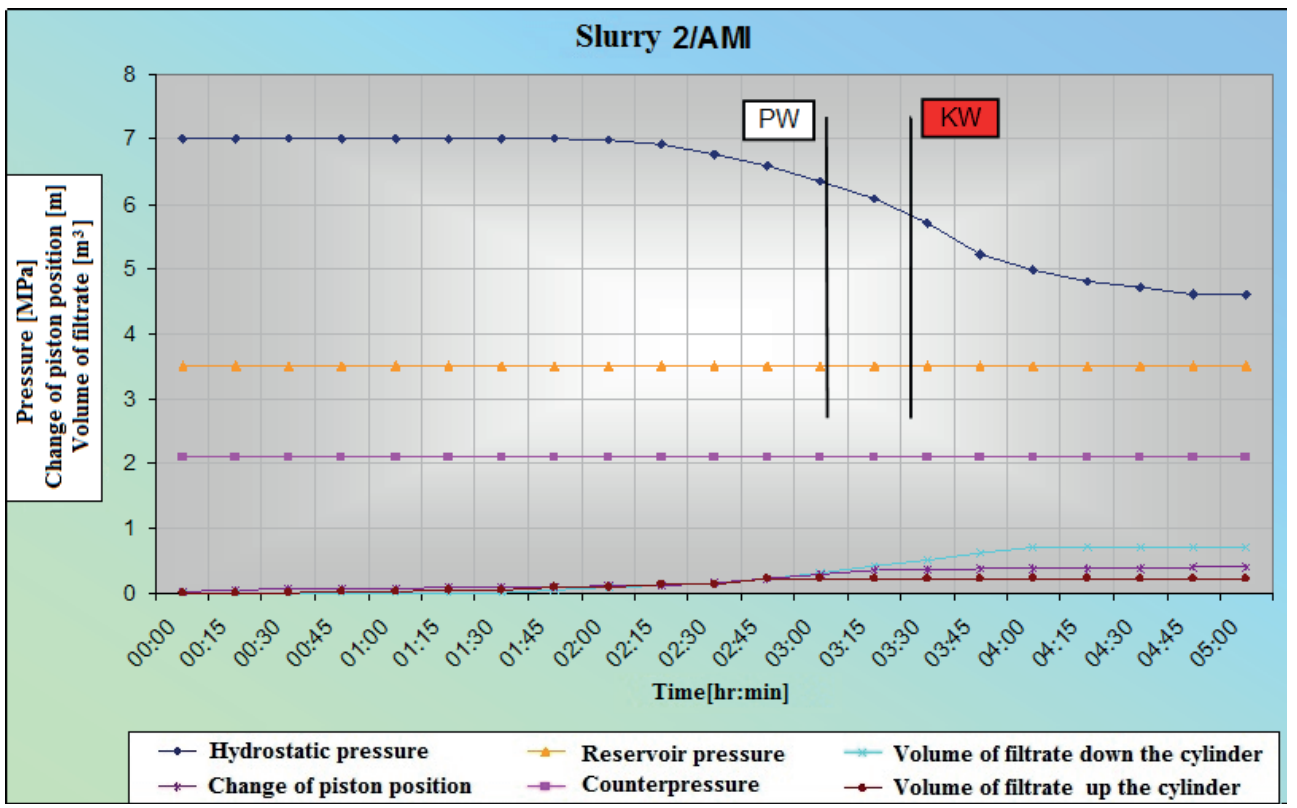

Fig. 12. Gas migration resistance test during bonding of slurry 2/AMI. Slurries for wellbore conditions at temp. $60^{\circ} \mathrm{C}$ and pressure $35 \mathrm{MPa}$. Slurry counteracting gas migration 


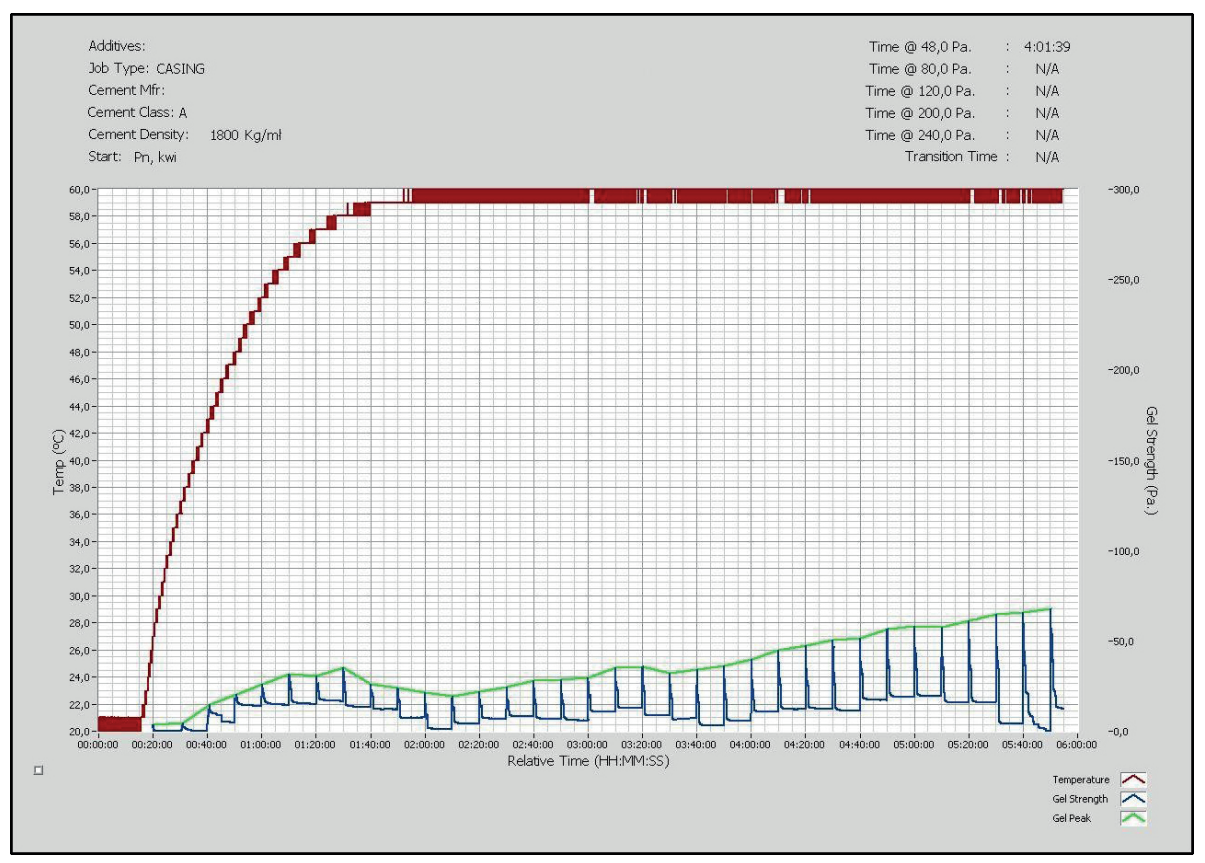

Fig. 13. Analysis of static structural strength increase of slurry $2 / B A Z$

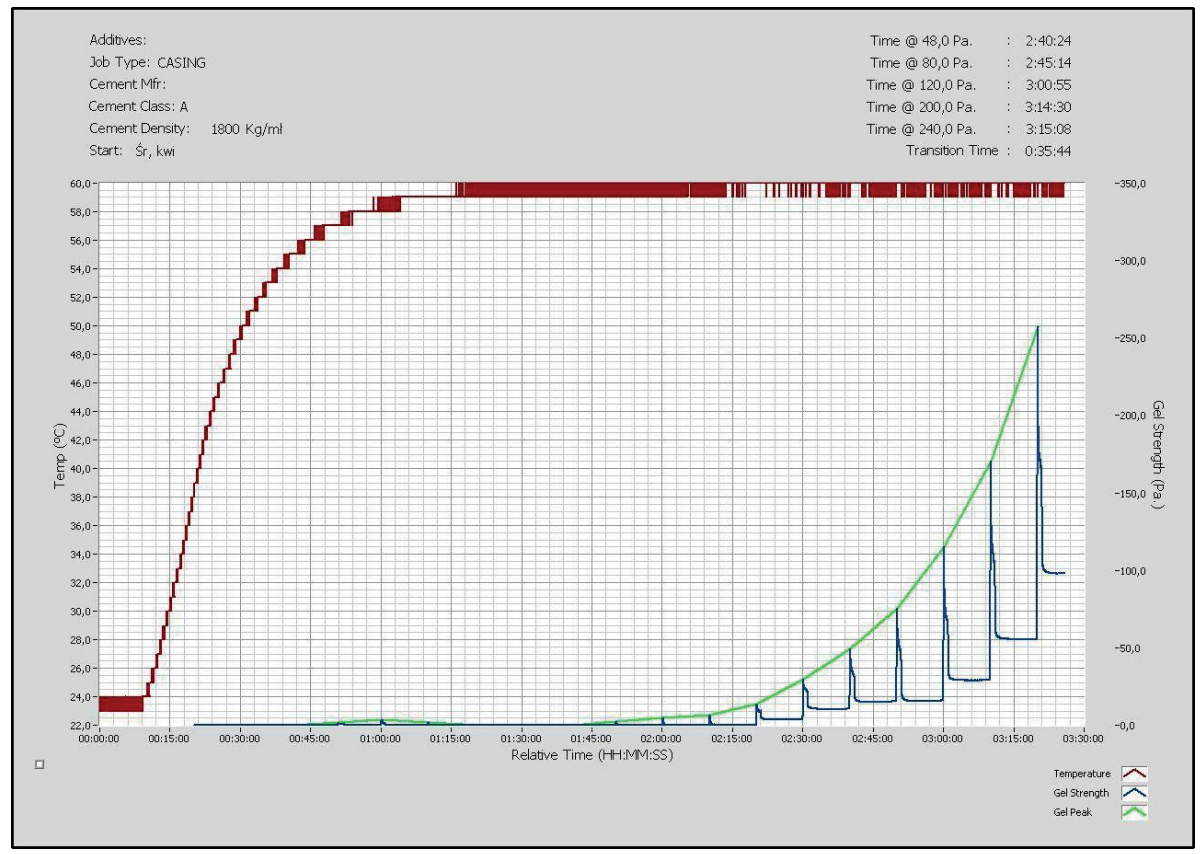

Fig. 14. Analysis of static structural strength increase of slurry 2/AMI 
After performing SSS analyses and the gas migration test a huge dependence was observed between them. Slurries resistant to gas migration maintain hydrostatic pressure of the column of cement slurry on a constant level in the course of bonding. The time when bonding ends was observed before the hydrostatic pressure dropped below the reservoir pressure at the final stage of cement slurry bonding (Figs. 8 and 12). Such slurries also reveal stability while building static structural strength. In the initial time of hydration the cement slurry had very low structural strength on the level of 0.5 to about $2 \mathrm{~Pa}$ (Figs. 10 and 14). When the bonding began and the hydrostatic pressure lowered in the gas migration test, a rapid increase of static structural strength could be observed (Figs. 10 and 14). This results in a short (51 minutes for slurry 1 and 35 minutes for slurry 2) transition time (TT) and so the ability to prevent gas migration through the cement slurry.

In the first test performed for the slurry which was not resistant to the gas migration effect, hydrostatic pressure of the slurry was lowered before the time of bonding ended (Figs. 7 and 11). The comparison of the static structural strength revealed that structural strength of the slurry was built very slowly. The transition time between $48 \mathrm{~Pa}$ and $240 \mathrm{~Pa}$ was over 2 hours for the first slurry (Fig. 9), whereas for the second slurry the TT value was not obtained (Fig. 13). During such an elongated gelling time gas may enter the structure of the bonding slurry and form its migration pathways. This test proves the negative result of the previous test, where the slurry did not have abilities to counteract gas migration processes.

\section{CONCLUDING REMARKS}

The analyses prove a considerable dependence of the results of gas migration resistance tests conducted in the process of cement slurry bonding and the analyses of the increase of static structural strength. The following conclusions have been drawn:

- The slurry hydrostatic pressure begins to drop (Figs. 8 and 12) when the structural strength begins to increase (Figs. 10 and 14).

- Slurries characterized by short transition times from $48 \mathrm{~Pa}$ to $240 \mathrm{~Pa}$ (TT) also reveal short transition time between the beginning of bonding (BB) and end of bonding (EB).

- Slurries of increased resistance to gas migration have a short transition time (TT) and quick bonding time; they also quickly thicken from $30 \mathrm{Bc}$ to $100 \mathrm{Bc}$ (Tab. 2).

- In slurries of long transition time (TT) and long bonding time from BB to EB gas may enter the structure of the bonding sealing slurry, and consequently gas flows may take place after the cementing.

- The beginning of slurry bonding was observed to correspond to the SSS values ca. 200-220 Pa.

The obtained results contribute to a better understanding of mechanisms in the bonding cement slurry, which may have effect on better sealing of wells where the risk of gas migration is high.

The gas migration tests in the course of cement slurry bonding, analysis of static structural strength, establishing the transition time, and also obeying regimes set before slurries greatly contribute to the lowering of the gas migration phenomenon. Attention should be paid to a number of other factors which have influence of the efficiency of sealing of the casing. Each cementing job should be analyzed individually with reference to the actual wellbore conditions. 


\section{REFERENCES}

[1] Crook R., Heathman J.: Predicting potential gas-flow rates to help determine the best cementing practices. Drilling Contractor 1998.

[2] Dębińska E.: Wyznaczanie statycznej wytrzymałości strukturalnej i wczesnej wytrzymałości mechanicznej zaczynów cementowych. Nafta - Gaz, nr 2, 2013.

[3] Kremieniewski M.: Proces migracji gazu w trakcie wiąania zaczynu cementowego. Nafta - Gaz, nr 3, 2011.

[4] Kremieniewski M., Rzepka M., Dębińska E.: Statyczna wytrzymałość strukturalna zaczynów GASBLOCK przeznaczonych do uszczelniania otworów o podwyższonym ryzyku występowania migracji gazu. Nafta - Gaz, nr 9, 2014.

[5] Oskarsen R.T., Wright J.W., Walzel D.: Analysis of gas flow yields recommendations for best cementing practices. World Oil, vol. 231, 2010.

[6] Pedam S.K.: Determining the strength parameters of oil well cement. University of Texas at Austin, May 2007.

[7] Radecki S., Witek W.: Dobór technik i technologii cementowania w aspekcie występowania migracji gazu. Nafta - Gaz, nr 9, 2000.

[8] Rogers M.J., Dillenbeck R.L., Eid R.N.: Transition Time of Cement Slurries, Definitions and Misconceptions, Related to Annular Fluid Migration. SPE Annual Technical Conference and Exhibition, Houston, Texas, 26-29 September 2004.

[9] Rzepka M.: Zaczyny cementowe do uszczelniania kolumn rur okładzinowych w głębokich otworach wiertniczych, w temperaturze dynamicznej do ok. $120^{\circ} \mathrm{C}$. Nafta - Gaz, nr 4, 2010.

[10] Stryczek S., Gonet A.: Kierunki ograniczania migracji gazu z przestrzeni pierścieniowej otworu wiertniczego. WUG: Bezpieczeństwo Pracy i Ochrona Środowiska w Górnictwie, $\mathrm{nr}$ 3, 2005, pp. 10-13.

[11] Stryczek S., Gonet A., Wiśniowski R.: Wpływ temperatury na właściwości technologiczne zaczynów uszczelniajacych stosowanych do prac geoinżynieryjnych. Wiertnictwo, Nafta, Gaz, t. 24, nr 1, 2007, pp. 519-534.

[12] Stryczek S., Wiśniowski R., Gonet A., Złotkowski A.: The influence of time of rheological parameters of fresh cement slurries. AGH Drilling, Oil, Gas, vol. 31, no. 1, 2014, pp. 123-133.

[13] Wiśniowski R., Stęperski P.: Wpływ parametrów reologicznych modelu Herschela-Bulkleyana wynoszenie zwiercin. Wiertnictwo, Nafta, Gaz, t. 25, nr 2, 2008, pp. 783-789. 